Tomasz Jeż

Instytut Muzykologii

Uniwersytet Warszawski

\title{
Z pamiętników muzykalnego humanisty. Schreibkalender Eliasa Maiora (1588-1669) jako źródło do historii kultury muzycznej Wrocławia
}

Przedmiotem artykułu są zapiski Eliasa Maiora - rektora Gimnazjum św. Elżbiety we Wrocławiu, zamieszczane w kolejnych Schreibkalender w latach 1640-1669. Stanowią one bogate źródło dokumentujące życie codzienne wrocławskich elit humanistycznych. Wśród zanotowanych przez wrocławskiego rektora relacji zwracają uwagę liczne wzmianki na temat muzyki, uprawianej zarówno w dziedzinie publicznej, jak i prywatnej.

The subject of the article are the notes by Elias Maior - a vice-chancellor of St. Elisabeth-Gymnasium in Wrocław - included in his successive diaries - Schreibkalender - written in 1640-69. They make a rich source documenting the everyday life of Wrocław humanist elites. There are among Maior's notes numerous references to music played both in public, and in private spheres.

Słowa kluczowe: Wrocław, humanizm, reformacja, Gimnazjum św. Elżbiety, Elias Maior

Ke y w o rds: Wrocław, humanism, Reformation, St. Elisabeth-Gymnasium, Elias Maior 
Założona przy kościele św. Elżbiety we Wrocławiu szkoła od połowy wieku XV była jednym z ważniejszych ośrodków humanizmu na Śląsku ${ }^{1}$. Wiązało się to $\mathrm{z}$ aktywnością działających $\mathrm{w}$ tym mieście erudytów, utrzymujących regularne kontakty naukowe $\mathrm{z}$ takimi humanistami jak: Gianfrancesco Poggio Bracciolini, Enea Silvio Piccolomini, Lorenzo Valla czy Konrad Celtis. To właśnie ich korespondentami i uczniami bywali hierarchowie wrocławskiej kurii i nauczyciele szkół tego miasta, najczęściej zresztą absolwenci Akademii Krakowskiej ${ }^{2}$. Szczególną rolę w tym gronie odegrał Wawrzyniec Korwin, który, kierując w latach 1497-1502 wrocławską szkołą św. Elżbiety, nadał obowiązującemu w niej programowi nauczania wyraźnie humanistyczny profil ${ }^{3}$. Program ten obejmował m.in. gruntowny kurs języka łacińskiego, lekturę autorów antycznych, a także teatr szkolny, zainicjowany przedstawieniami komedii Terencjusza i Plauta. Humanistyczny światopogląd Korwina wyrastał z idei neoplatońskich, uzasadniających nie tylko uniwersalizm kultywowanej przezeń czynnie tradycji literackiej, ale też jej odniesienia do koncepcji harmonii sfer niebieskich ${ }^{4}$, świata chrześcijańskich wartości moralnych ${ }^{5}$ i doświadczeń religijnych, ujawnionych w oryginalnej adaptacji pism św. Bonawentury stworzonej na potrzeby liturgii pasyjnej we wrocławskiej farze ${ }^{6}$.

Najprawdopodobniej to właśnie Korwin był adresatem listu Filipa Melanchtona z 19 lutego 1521 r. ${ }^{7}$, w którym na ręce kolejnego przełożonego elżbietańskiej szkoły - Johannesa Trogera - praeceptor Germaniae kierował słowa uznania wobec programu dydaktycznego tej placówki.

${ }^{1}$ G. Bauch, Geschichte des Breslauer Schulwesens in der Zeit der Reformation, Breslau 1911 (Codex Diplomaticus Silesiae, t. 26), s. 200-239.

${ }^{2}$ Zob. idem, Beiträge zur Literaturgeschichte des schlesischen Humanismus, „Zeitschrift des Vereins für Geschichte und Altherthum Schlesiens”, 30, 1896, s. 127-164.

${ }^{3}$ Zob. idem, Laurentius Corvinus, der Breslauer Stadtschreiber und Humanist, "Zeitschrift des Vereins für Geschichte und Althertum Schlesiens”, 17, 1883, s. 230-302.

${ }^{4}$ Carmen elegiacum Magistri Laurentij Coruini [...] De Apolline et nouem Musis, Breslau 1503, BJ, sygn. St. Dr. Cim. 5151.

${ }^{5}$ Dialogus [...] de mentis saluberrima persuasione [...], Lipsiae 1516, BUWr, sygn. 462103.

${ }^{6}$ Cursus Sancti Bonaventurae de passione domini cum invitatorio himnis et canticis Laurentij Corvini, Breslau 1521, BPAU-PANKr, sygn. Cim. 80 I. G.

7 Philippi Melanchthonis opera quae supersunt omnia, hrsg. von C. G. Bretschneider, Halle 1834 (Corpus Reformatorum, t. 1), s. 283; G. Bauch, Geschichte des Breslauer Schulwesens, s. 39. 
Koncepcja pedagogiczna łącząca edukację humanistyczną z formacją religijną i wychowaniem obywatelskim doskonale zresztą odpowiadała wizji Melanchtona, również wychowawcy i promotora kilku pokoleń wrocławskich pastorów i nauczycieli ${ }^{8}$. To za owoc jego starań uznaje się specyficznie ugodowy charakter śląskiego ewangelicyzmu, którego działacze wprowadzali pierwsze reformy w sposób stopniowy i - znacznie bardziej niż gdzie indziej - kompromisowy ${ }^{9}$. Sukcesywnym zmianom porządku liturgii w kościołach Wrocławia $^{10}$ towarzyszyły modyfikacje programu nauczania w szkołach tego miasta; kluczowym podmiotem tych zmian był zaś jego magistrat, nadzorujący procedury kształcenia w szkołach, wysyłający ich absolwentów na studia i wymagający od nich później podjęcia pracy w rodzinnym mieście ${ }^{11}$. Efektem tej doskonale zorganizowanej symbiozy instytucjonalnej była coraz większa samodzielność elit miasta i umiejętność skutecznego przeciwstawienia się rosnącym wpływom Habsburgów i kontrreformacji.

Uważa się, że filipistyczny humanizm do lat osiemdziesiątych XVI w. konstytuował ideowy profil śląskiego luteranizmu; w późniejszych latach bowiem jego koncyliacyjne oblicze stopniowo zaczęła opanowywać coraz bardziej radykalna formuła, która ostatecznie doszła do głosu w czasach wojny trzydziestoletniej ${ }^{12}$. Czy jednak humanistyczny irenizm, zaszczepiony wrocławskim elitom przez Melanchtona, definitywnie uległ znacznie bardziej radykalnej wizji Lutra i wywiedzionej zeń tzw. ortodoksji luterańskiej, która w połowie wieku XVII rzeczywiście stała się narracją dominującą, nawet na Śląsku? Odpowiedzi na to pytanie poszukamy w unikatowym dokumencie epoki - pamiętnikach Eliasa Maiora, długoletniego rektora elżbietańskiego gimnazjum ${ }^{13}$.

${ }^{8}$ Ch. Absmeier, Szkoty a region: szkolnictwo ślaskie wieku reformacji, tł. M. Kulisz, „Śląska Republika Uczonych”, 3, 2008, s. 123.

9 Zob. J. Harasimowicz, Śląki luteranizm wieku Reformacji-próba charakterystyki, „Śląski Kwartalnik Historyczny Sobótka”, 34, 1984, nr 4, s. 493-516.

${ }^{10}$ Opisuje je szczegółowo H.-A. Sander, Beiträge zur Geschichte des Lutherischen Gottesdienstes und der Kirchenmusik in Breslau. Die lateinische Haupt- und Nebengottesdienste im 16. und 17. Jahrhundert, Breslau 1937, passim.

11 Zob. T. Jeż, Stypendia wroctawskiej Rady Miejskiej jako instytucja ksztatcenia kadr muzycznych w latach 1550-1650, „Sląska Republika Uczonych”, 3, 2008, s. $155-181$.

12 M. P. Fleischer, Die Konkordienformel in Schlesien, „Jahrbuch für schlesische Kirchengeschichte", 58, 1979, s. 52-54; J. Harasimowicz, op. cit., s. 497.

${ }^{13} \mathrm{~J}$. C. Arletius, Historischer Entwurf von den Verdiensten der Evangelischen Gymnasiorum in Breslau um die deutsche Schaubühne, Breslau 1762, s. 42; M. Hippe, 
Zanim jednak przyjrzymy się bliżej obrazowi życia codziennego przedstawionemu przez tego wrocławskiego nauczyciela i humanistę, zobaczmy, w jaki sposób życie to było zorganizowane w latach wcześniejszych.

Za postać kluczową uznać trzeba Ambrosiusa Moibana (1494-1554). Po studiach w Krakowie i Wiedniu wydał on drukiem wybór hymnów Giovanniego Pico della Mirandoli i listów Erazma z Rotterdamu, a w 1520 r. trafił do Wittenbergi, gdzie pobierał nauki u Melanchtona i Lutra. Studia zwieńczyło powołanie w 1525 r. na stanowisko proboszcza kościoła św. Elżbiety ${ }^{14}$. Reorganizacji liturgii towarzyszyło unormowanie programu dydaktyki w szkołach, przeprowadzane przez kolejnych przełożonych ${ }^{15}$. W charakteryzującym ich sposobie wdrażania reform szkolnych widać pełną rozwagi optykę Melanchtona: według opracowanej np. przez Moibana Schulordnung z 1528 r. program nauki szkolnej koncentrować się miał na oryginalnych źródłach Biblii i obejmować wykład gramatyki i praktykę muzyczną ${ }^{16} . \mathrm{Z}$ inspiracji Melanchtona w programie nauczania wrocławskiej szkoły znalazły się również łacińskie deklamacje, które służyły uczniom jako ćwiczenia w łacinie i pomoc w poznawaniu przez nich osobliwości ludzkiej natury ${ }^{17}$. W realizacji programu nauczania posiłkowano się też publikacjami Moibana, obejmującymi m.in. wydany jeszcze w Lipsku podręcznik gramatyki łacińskiej ${ }^{18}$, często wznawiany katechizm z przedmową Melanchtona ${ }^{19}$ i edycję

Aus dem Tagebuche eines Breslauer Schulmannes im siebzehhnten Jahrhundert, w: Breslauer Studien. Festschrift des Vereins fur Geschichte und Althertum Schlesiens zum fünfundzwanzigjährigen Amtsjubiläum seines Vizepräses Hermann Markgraf, Breslau 1901, s. 159-192.

${ }^{14}$ J. Soffner, Geschichte der Reformation in Schlesien, Breslau 1886, s. 41-46; P. Konrad, Die Einführung der Reformation in Breslau, Breslau 1917, s. 65-67.

15 Proces kształtowania się programu nauczania szkolnego w protestanckich gimnazjach Wrocławia prezentuje J. Budzyński, Paideia humanistyczna czyli wychowanie do kultury. Studium z dziejów klasycznej edukacji w gimnazjach XVI-XVIII wieku (na przyktadzie Ślaska), Częstochowa 2003, s. 61-67, 96-105, 140-145.

$16 \mathrm{~J}$. Sass, Die kirchenmusikalischen Ämter und Einrichtungen an den drei evangelischen Haupt- und Pfarrkirchen der Stadt Breslau, Breslau 1922, s. 27-28, 41-42.

${ }^{17}$ Por. list Melanchtona z 17 IV 1520 r. do Johannesa Hessa, pastora wrocławskiego kościoła św. Marii Magdaleny, w: Philippi Melanchthonis opera, s. 135.

${ }^{18}$ Pedia artis grammaticae Ambrofii Moibani [...] Adiectus est libellus Eras [mi] Rote[rodami] de conftructione [...], Lipsiae 1522, BUWr, sygn. 442131.

${ }_{19}$ Catechismi capita decem, primum quibufdam thematis, Deinde etiam Colloquiis puerilibus illuftrata, iunentuti Vuratislauienfi proposita [...], Vitebergae 1538, BUWr, sygn. 301174. 
komedii Terencjusza, opatrzoną komentarzami Melanchtona oraz wstępem Moibana ${ }^{20}$.

Dwie ostatnie pozycje opublikował Andreas Winkler (1498-1575), który od 1526 r. był przełożonym wrocławskiej szkoły św. Elżbiety ${ }^{21}$. Również i on studiował w Krakowie oraz Wittenberdze, gdzie uzyskał magisterium pod kierunkiem Melanchtona; jego promotor wygłosił zresztą przy tej okazji laudację (wydaną też drukiem). To właśnie Winkler podporządkował swą szkołę administracji i budżetowi miejskiego magistratu. Systematycznie zabiegał o przekształcenie szkoły w uczelnię wyższą, do czego pierwszym krokiem było nadanie jej w 1562 r. statusu gimnazjum. Jako pierwszy rektor Elisabetanum, Winkler rozwinął program nauczania placówki, zwiększając liczbę klas $\mathrm{z}$ trzech do pięciu. Posiłkując się instrukcjami Melanchtona, wzbogacił też listę lektur o kolejnych autorów łacińskich, greckich oraz prace z zakresu dialektyki, retoryki i teologii. Drukował je w uruchomionej przez siebie w 1538 r. oficynie, ciesząc się przywilejem magistratu (a później i cesarza!) na publikowanie podręczników szkolnych. Na liście jego edycji znajdujemy listy Cycerona, ody Horacego, pisma Arystotelesa i św. Augustyna, epigramaty Melanchtona, wspomniane już komedie Terencjusza oraz prace Moibana, a także traktat z zakresu teorii muzyki ${ }^{22}$.

Reformy szkolne Winklera kontynuował jego następca, Petrus Vincentius (1519-1581), kolejny uczeń Lutra i Melanchtona, który po studiach pracował jako nauczyciel w Lubece, Wittenberdze i Zgorzelcu, by w 1569 r. powrócić do rodzinnego Wrocławia. Niedługo po objęciu funkcji rektora w Elisabetanum oraz inspektora szkolnego, opublikował w 1570 r. nowy Porzadek szkolny, bazujący na wprowadzonych dotychczas reformach Winklera. Wprowadził m.in. pięcioklasowy cykl nauki $\mathrm{w}$ gimnazjum i ustalił listę przypisanych do poszczególnych klas lektur ${ }^{23}$. Obejmowały one w zakresie łaciny dzieła Cycerona, Plauta, Owidiusza, Terencjusza, Wergiliusza, w dziedzinie greki - utwory Demostenesa, Hezjoda, Homera, Ewangelie i listy św. Pawła, a nadto teksty z zakresu dialektyki, retoryki oraz teologii

${ }^{20}$ P. Terentii Comoediae [...] Accesservnt praeter argumenta Philippi Melanch. [...], Breslau 1540, BUWr, sygn. 304514.

${ }^{21}$ Zob. M. Burbianka, Andrzej Winkler - drukarz wroctawski XVI wieku, „Roczniki Biblioteczne", 4, 1960, s. 329-445, 636-638.

22 Erotemata Mvsicae Practicae ad captum puerilem formata, Virgilio Haug autore [...], Vratislaviæ 1541, BUWr, sygn. 380605.

${ }^{23} \mathrm{~J}$. Budzyński, op. cit., s. 131-135. 
(oparte na Examen theologicum Melanchtona) i wybrane księgi Biblii (studiowane w językach oryginalnych). Wykłady z teologii odbywały się w położonym nad zakrystią kościoła św. Elżbiety Auditorium theologicum, co znacząco podkreślało związek szkoły i parafii ${ }^{24}$. Humanistyczne horyzonty wrocławskiego rektora potwierdzają również jego edycje, m.in. komedii Plauta, traktatów Erazma czy epigramatów Melanchtona ${ }^{25}$.

O zakrojoną na tak szeroką skalę edukację humanistyczną dbali następcy Vincentiusa: Nikolaus Steinberg (na stanowisku rektora Elisabetanum w latach 1578-1610), Petrus Kirstenius (1610-1616), a przede wszystkim Thomas Sagittarius (1616-1621), autor wielu publikacji, uhonorowany tytulem poeta laureatus ${ }^{26}$. $\mathrm{Na}$ ich czasy przypadła jednak, brzemienna w skutkach, konfrontacja śląskiego ewangelicyzmu z nasilającymi się tendencjami rekatolizacyjnymi, a także z nurtem teologii skłaniającej się ku kalwinizmowi, coraz bardziej popularnemu wśród spadkobierców myśli Melanchtona ${ }^{27}$. Ruchy te doprowadzity z jednej strony do definitywnego zerwania związków z katolicyzmem, z drugiej zaś przyczynity się do konsolidacji protestantyzmu, zogniskowanego odtąd raczej wokół myśli Lutra niż Melanchtona. Zwolenników filipizmu pozbawiano (jako kryptokalwinistów) urzędów nauczycielskich i duszpasterskich, powoływanych zaś na te stanowiska teologów obligowano do lojalności wobec luterańskiej ortodoksji. Deklaracje tego typu, składane przez Steinberga, Kirsteniusa i Sagittariusa ${ }^{28}$, nie przeszkodziły im jednak w podtrzymywaniu tradycji filologicznej zaszczepionej przez Melanchtona elitom Wrocławia i kultywowanej przez jej reprezentantów w placówkach edukacyjnych miasta.

Kluczową rolę odegrał tu Elias Maior (Major), który posadę rektora Elisabetanum objął po Michaelu Polliusie (1621-1631) i piastował ją przez kolejne 38 lat. Maior urodził się we Wrocławiu 26 lutego 1588 r. jako syn szewca, Eliasa Grossera. Naukę pobierał najprawdopodobniej w tamtejszym Gimnazjum św. Elżbiety, właśnie Steinberga i Kirsteniusa wspominał bowiem jako świetnych wychowawców

${ }^{24}$ K. Garber, Das Alte Breslau. Kulturgeschichte einer geistigen Metropole, Köln-Weimar-Wien 2014, s. 135.

${ }_{25}$ M. Burbianka, op. cit., s. 416.

${ }^{26} \mathrm{~J}$. L. Flood, Poets Laureate in the Holy Roman Empire. A Bio-bibliographical Handbook, vol. 4: S-Z, Berlin 2006, s. 1794 n.

27 J. Harasimowicz, op. cit., s. 503-505.

${ }^{28}$ G. Bauch, Geschichte des Breslauer Schulwesens, s. 241-242. 


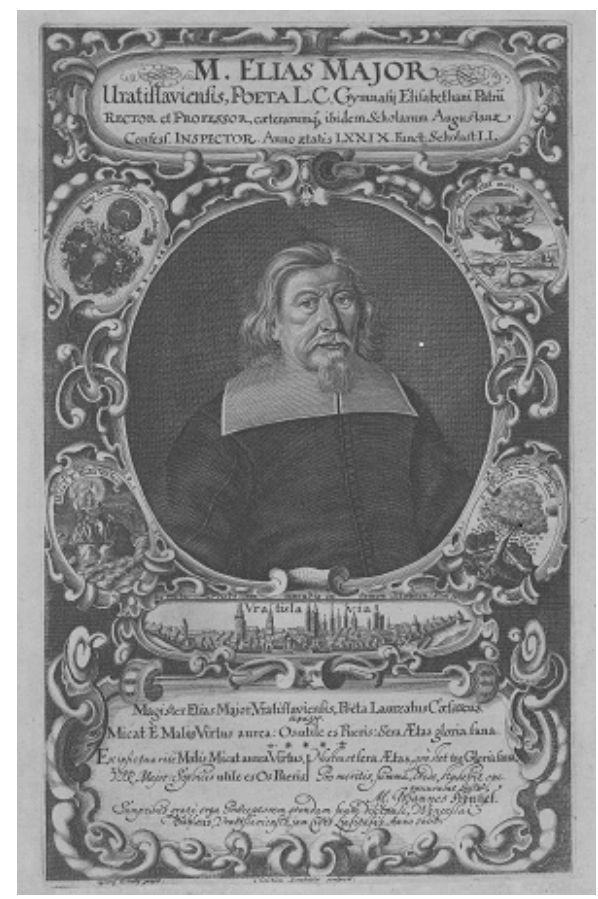

Il. 1. Elias Maior, sztych Christiana Romsteta z 1667 r. (Universitätsbibliothek Leipzig, Porträtstichsammlung, Inventar-Nr. $31 / 56)$

i erudytów ${ }^{29}$. W kwietniu 1610 r. otrzymał od Rady Miasta stypendium (w wysokości 57 talarów rocznie) na studia teologiczne w Wittenberdze, które rok później zostało przedłużone i było wypłacane do roku $1615^{30}$. Poza studiowaniem teologii i filozofii Maior angażował się w życie muzyczne miasta; wraz z innymi studentami ze Śląska założył tam także Collegium declamatorium privatum (jego członkowie co tydzień wystawiali przedstawienia teatralne $)^{31}$. Po uzyskaniu magisterium, zgodnie z umową stypendialną, Maior oddał się do dyspozycji wrocławskiego magistratu. 18 marca 1615 r. został przezeń powołany

${ }^{29}$ J. H. Cunradus, Silesia Togata, ed. by C. T. Schindlerus, Lignicii 1706, s. 181; G. Bauch, Geschichte des Breslauer Schulwesens, s. 318, 339.

30 AP we Wrocławiu, Akta miasta Wrocławia, zespół 28, 3944 (olim: P 31), „Stipendiaten-Rechnungsbuch", k. 128ver.-129rec.

31 M. Hippe, op. cit., s. 160. 
jako Collega tertii ordinis w Elisabetanum ${ }^{32}$, a kilka miesięcy później objął również obowiązki nauczyciela muzyki ${ }^{33}$. Od 1617 r. był notowany jako Collega primi ordinis i Professor historiarum et oratoriae.

Intelektualne kwalifikacje Eliasa Maiora dobitnie potwierdza tytuł poeta laureatus, przyznany mu 1 maja $1631 \mathrm{r} .{ }^{34}$, a także wybór tydzień później na stanowisko rektora Gimnazjum św. Elżbiety ${ }^{35}$. Funkcję tę piastował on aż do śmierci, 17 lipca 1669 r. Prywatnie Maior był od 1618 r. mężem Marii Profe, córki wrocławskiego sukiennika Daniela i siostry Ambrożego (1589-1661), znanego Eliasowi z czasu wspólnych studiów w Wittenberdze, czynnego później (w latach 1633-1649) jako organista kościoła św. Elżbiety we Wrocławiu ${ }^{36}$. Maria i Elias mieli ośmioro dzieci, ale wiadomości mamy jedynie o trzech synach pary: najstarszy Esaias pracował jako prawnik w Jaworze, Elias junior pełnił obowiązki prorektora szkoły w Oleśnicy, a później nauczyciela w Elisabetanum, Johann Daniel zaś - profesora medycyny na uniwersytecie w Kilonii ${ }^{37}$. W przeciwieństwie do swoich synów, Elias Maior niemal całe życie spędził we Wrocławiu, poświęcając czas przede wszystkim kierowanemu przez siebie Gimnazjum św. Elżbiety. Ponieważ w imieniu wrocławskiego magistratu sprawował jednocześnie funkcję inspektora szkolnego, doglądał procedur kształcenia także w innych szkołach miasta, szczególnie w szkole św. Marii Magdaleny, która w 1643 r. uzyskała status gimnazjum i m.in. za sprawą Maiora otrzymała w tym roku własną Schulordnung ${ }^{38}$.

Sylwetkę wrocławskiego rektora Elisabetanum przybliżają wydane przezeń publikacje, najczęściej związane z aktywnością nauczycielską. Zachowały się jednak również jego epigramaty ${ }^{39}$, wiersze o treści filozo-

${ }^{32}$ M. Hancke, Vratislaviensis Eruditiones Propagatores: Id est, Vratislaviensium Scholarum Presides, Inspectores, Rectores, Professores, Praeceptores Tabulis Chronologicis comprehensi, Leipzig 1701, s. 23.

${ }^{33}$ AP we Wrocławiu, Akta miasta Wrocławia, zespół 28, 3944, k. 129rec.: ,ist am 1615 Junii S. Elisabeth in locum cantoris in schola sustineret"; por. T. Jeż, op. cit., s. 170.

${ }^{34}$ J. L. Flood, Poets Laureate in the Holy Roman Empire. A Bio-bibliographical Handbook, vol. 3: $L-R$, Berlin 2006, s. 1233-1237; K. Garber, op. cit., s. 153.

${ }^{35}$ M. Hancke, op. cit., s. 28.

${ }^{36}$ R. Starke, Ambrosius Profe, „Monatshefte für Musikgeschichte”, 34, 1902, nr 11, s. 189-196; nr 12, s. 199-215.

${ }^{37}$ M. Hippe, op. cit., s. 161.

${ }^{38}$ J. Budzyński, op. cit., s. 140-141.

${ }^{39}$ M. Eliae Majoris anagrammatum semicenturia [...], Vratislaviæ [1634], BN, sygn. SD XVII.3.16748; Epigrammata quaedam miscella [...], Vratislaviæ [1641], BN, 
ficznej, okolicznościowej i moralnej ${ }^{40}$, parafrazy psalmów ${ }^{41}$ oraz poezje religijne, głównie o tematyce pasyjnej ${ }^{42}$. Zdecydowanie najliczniejszą grupę druków sygnowanych jego nazwiskiem stanowią jednak programy szkolnych deklamacji, wystawianych przez uczniów kierowanego przezeń gimnazjum ${ }^{43}$. Są to wierszowane łacińskie oraz niemieckie exercitia scholastica o tematyce historycznej ${ }^{44}$, politycznej ${ }^{45}$, biblijnej ${ }^{46}$, religijnej ${ }^{47}$

sygn. SD XVII.3.17021; Primitia Epigrammatum Magnificis Munificisq[ae] Patronis [...], Breslæ [1645], BUWr, sygn. 445373.

${ }^{40}$ M. Eliae Majoris L. Parodic, ad illud, Omnia fi perdas \&oc. [...], Vratislaviæ [po 1636], BUWr, sygn. 354954.

${ }^{41}$ M. Eliae Maioris Vratislaviensis Psalmus Davidicus unus \& nonagesimus, Rysiou instar, pro divina, contagioso tempore protectione, Vratislaviæ 1626, BUWr, sygn. 354957; Psalmus Davidis CIII.: Carmine Heroico Expressus Deo Protectori, Consolatori, Liberatori Opt. Max. Sacrum Esse Voleb. Voti Damnas M. Elias Major, Vratislaviæ 1629, BUWr, sygn. 354958; Psalmus Davidicus Centesimus Septimus: Hexametro Carmine expressus \& Deo Custodi atq[ue] Opitulatori consecratus a M. Elia Majore Vratisl. P. L. C., Vratislaviæ 1634, BUWr, sygn. 354959.

${ }^{42}$ Die Sieben Georgii Fabricii, auß des H. Christi Sieben Worten am Creutze abgefaste Andachten [...] auß dem Latein ins Deutsche versetzt von M. Elia Maiore, Breßlaw 1646, BUWr, sygn. 354943; Das Leyden unseres Heylandes: auß dem Lateinischen Johannis Claji uberge etzt, mit Dreyen darzu gefügten Leidens-Andachten von M. Elia Majore, Breßlaw [1650], Berlin, Staatsbibliothek Preußischer Kulturbesitz, sygn. Yi 2766.

43 Por. J. Budzyński, op. cit., s. 405, 407, 416, 417.

${ }^{44}$ Dissertatiunculas de Urbe Roma deque Regibus Romanis, cum quibusdam Synchronifmis a. d. XXX. Julii Ann. Chrift. M DC XLVIII. in Gymnafio

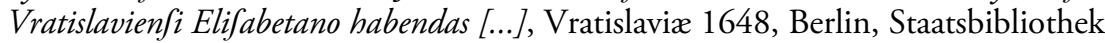
Preußischer Kulturbesitz, sygn. Ah 16124/8; De Carolo Quarto Rom. Imperatore \& Bohem. Rege Urbis Vratislavic [...] amplificatore, exercitiis nonnullis juvenilibus mentionem Sacularem in Gymnafio Vratislavienfium Elifabetano [...] faciendam indicit M. Elias Major, laudati Gymnafii Rector, Vratislaviæ 1653, Berlin, Staatsbibliothek Preußischer Kulturbesitz, sygn. Ah 16124/27; Ex Q. Curtii Libri tertii capitibus fex primis Oratiunculas In Gymnafio Elifabetano A. D. VI. Non. Majas ann. Chr. CID IDC LVIII habendas, indicit M. Elias Major, Gymnafii Rector, Vratislaviæ 1648, Berlin, Staatsbibliothek Preußischer Kulturbesitz, sygn. Ah 16124/34.

45 Dissertationes scholasticas et Politicorum Inftitutionibus De abfolutè Imperantium Poteftate, atque Majeftate [...] indicit Elias Major, Vratislaviæ 1652, Berlin, Staatsbibliothek Preußischer Kulturbesitz, sygn. Ah 16124/24.

46 Quod bene vertat! Execitatia scholastica altera ex historia Jonae \& Ninivitarum, itemq[ue] ex Hymno Josaphati, a. d. 18. Decembr. Ann. 1642. in Elisabetano Gymnasio, habenda indicit M. Elias Major Rector, Breslae 1642, BUWr, sygn. 539011.

47 Sacra quaedam exercitia de angelis a.d. Prid. Non. Octobr. ann Chr. CID IDC XXXIX in Gymnasio Vratislaviensi recitanda indicit M. Elias Major, rector, 
i okolicznościowej ${ }^{48}$, m.in. z okazji stulecia śmierci Filipa Melanchtona ${ }^{49}$. Niektóre $\mathrm{z}$ tych przedstawień bazowały na tekstach autorów antycznych: Horacego, Seneki i Cycerona ${ }^{50}$, należących do kanonu lektur wrocławskiego gimnazjum. Śladem dydaktycznej aktywności Maiora jest też opracowany przezeń łaciński słowniczek ${ }^{51}$, mowy szkolne jego autorstwa ${ }^{52}$ i wydany już pośmiertnie podręcznik gramatyki ${ }^{53}$. Aktywną obecność Maiora w życiu wrocławskich elit poświadczają również jego poezje okolicznościowe. Znajdujemy je w zawierających utwory wielu autorów zbiorach: epitalamiów ${ }^{54}$

Vratislaviæ [1639], BN, sygn. SD XVII.3.4953 adl.; Soteria in Gymnasio Vratislaviensi A. D. IV Cal. April. Ann. Christ. CID IDC XLIX Celebranda Indicunt M. Elias Major Rector, \& Christophorus Colerus Conrector, Vratislaviæ [1641], Berlin, Staatsbibliothek Preußischer Kulturbesitz, sygn. Ah 16124/1; Meditationes passionales ex psalmo XXII potissimum susceptas an. Chr. CID IDC XLII a.d. XIV Cal. Majas horis a prima pomeridianis in Gymnasio Vratislaviensi recitandas indicit M. Elias Major, Breslæ [1642], BN, sygn. SD XVII.3.4966 adl.

${ }^{48}$ Exercitium Poëticum Vota Pro Felici Novo Anno complexum, A.D. XIX. \& XVIII. Calend. Febr. publice habendum indicit M. Elias Maior Vratislavienfis Hiftor, Profeffor, Vratislaviæ 1625, Berlin, Staatsbibliothek Preußischer Kulturbesitz, sygn. Xc 567/41; Exercitia scholastica de oleâ, pietatis novo anno rite inchoando [...] in Gymnasio Elifabetano habenda [...], Vratislaviæ 1649, Berlin, Staatsbibliothek Preußischer Kulturbesitz, sygn. Ah 16124/12.

49 Secularem Melanchthoniani Diei Emortualis, memoriam in Gymnafio Vratislavien ${ }_{i}$ Elifabetano a. d. IV. Non. Majas Anni Chr. CID IDC LX [...] recolendam indicit M. Elias Major Rector, Vratislaviæ 1660, BUWr, sygn. 444378.

50 L. Annai Seneca De Providentia Caput Terrium Pro Nundinali Lectione defcribi curabat M. Elias Major [...], Vratislaviæ 1648, BUWr, sygn. 444335; Romanum de capite Horatii judicium liberalis exercitionis causa ex Junianis orationibus lingva Germanica in Gymnasui Elisabetano [...] indicit M. Elias Major, Vratislaviæ [1649], Warszawa, BN, sygn. SD XVII.3.4962 adl; De M. Tullio Cicerone, ante ipfa facula decem \& feptem interemto, ex Plutarchi potisfimum historiâ exercitia scholastica [...] in Gymnafio Elifabetano [...] recitanda, Vratislaviæ 1658, Berlin, Staatsbibliothek Preußischer Kulturbesitz, sygn. Ah 16124/37.

51 Dictionarium nominum verborumque secundum accidentia Grammatices Latine digestorum [...], Breslau 1620, BJ, sygn. 19809-I.

${ }^{52}$ M. Elie Maioris Orationes Tres In Gymnasio Vratislaviensi Habite, Lipsiæ 1626, BN, sygn. SD XVII.1.955.

${ }^{53}$ M. Elice Majoris Vratislaviensis [...] Liber Postvmvs De Varianda Oratione, Ad Lectionem Veterum, Et Sermonis Puri Copiam Parandam In Primis Necessarius [...], Vratislaviæ 1684, Berlin, Staatsbibliothek Preußischer Kulturbesitz, sygn. Wa 1390.

${ }^{54}$ Viro Quâ dignitatem, Venerabili [...] Johanni Tralles, Pastori Ecclefia Hirschbergensis [...] Sponso [...], cum Catharina, Dn. Georgi VVolfgruberi Senatoris Reipubl. eiufdem [...] Filia [...], [Wrocław] 1620, Berlin, Staatsbibliothek Preußischer Kulturbesitz, sygn. Xc 573/45; Felicitatem Conjugalem Viro Reverendo [...] Dn. 
dedykowanych nowożeńcom, gratulacji składanych znajomym z okazji imienin lub urodzin ${ }^{55}$ czy epitafiów poświęcanych pamięci zmarłych ${ }^{56}$. Elias Maior sam był zresztą adresatem analogicznych poezji: epigramatów powstałych przy okazji nadania mu tytułu poeta laureatus ${ }^{57}$, imieninowych i urodzinowych gratulacji ${ }^{58}$ czy wieńczących jego życie neniów ${ }^{59}$. Jeśli to specyficzne przemieszanie oficjalnej, urzędowej

M. Abrahamo, Andrea F. Eccardo, Ecclefice Namflaviensis Diacono Fidelifsimo: Virginum [...] Annam [...] Dn. Pauli Neandri, Advocatic, que Vratislavice eft [...] Filiam, [...] in matrimonium ducenti [...], Vratislaviæ 1645, Berlin, Staatsbibliothek Preußischer Kulturbesitz, sygn. Yf 6807/24; Honeftifsimis Sponfis, Eruditissimo Viro, M. Johanni Balthasari Cargio, In Elifabethano \& Barbarino Templo apud Vratislavienses chori Musici Prafecto, \& in Gymnafio, quod illi vicinum est Adi, College bene merenti, atque [...] Virgini, Elisabete [...] Georgii Weirauchii [...] Filia Unice, Matrimonium [...], Vratislaviæ 1665, Berlin, Staatsbibliothek Preußischer Kulturbesitz, sygn. Yf 6807/65.

55 In Hoffmanniana Nominalia [...] Anni CID IDC XXXIII extremi, Duo M. E. M. Poëmata [...], Vratislaviæ [1633], BUWr, sygn. 440068; Nobilis, Clarifsimi, Confultifsimiq; Viri Dn. Thoma Schroerijcti [...] Onomasteria [...] M. Elia Majore P. L. C., Breslæ [1641], BUWr, sygn. 442792. O konktaktach Eliasa Maiora $\mathrm{z}$ adresatem dedykacji pierwszego $\mathrm{z}$ wymienionych tu poematów, Christianem Hoffmannem von Hoffmannswaldau - jego uczniem z Elisabetanum, a później wybitnym poetą śląskiego baroku - pisał już L. Noack, Christian Hoffmann von Hoffmannswaldau (1616-1679). Leben und Werk, Tübingen 1999, s. 54-55, 146-147, 151, 208, 220, 231, 308, 320, 379.

${ }^{56}$ Epitaphium Anne Closie, Virginis [...] Florentissima; Ejusdem Parenti [...] M. Henrico Closio, Gymnafii Magdalenei Vratislavienfis Rectori [...] confolaitonis ergo exhibitum a M. Elias Majore, P. L. C. Gymnasii Vratislaviensis Elifabetani Rectore [...], [Wrocław, po 1644], BUWr, sygn. 412691; Erimiis Virtutibus [...] Johannis ab Haunoldt [...] Ann. 1655 [...] consecrate a Clientibus Epicedia,

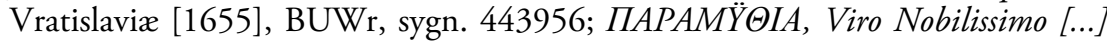
Domino Godofredo Wolffio, J.U. Licent. Illustriss. Comitis ab Hazfeld, \& Gleichen, Liberi Baronis in Wildenberg \& Trachenberg, Consiliario longe dignifsimo, lugenti Obitum prematurum Filii dilecticsimi, Adolescentuli Godofredi Wolffi [...], Vratislaviæ 1660, Berlin, Staatsbibliothek Preußischer Kulturbesitz, sygn. Xc 577/39.

${ }^{57}$ Elice Maioris Vratislaviensis Ann. Chr. M.DC.XXXI Calendis Majis, Laurea Casarea Poetica solemniter redimiti, \& VIII. Idus Majas Rectoris Gymnasii Vratislaviensis, publice \& legitime renunciati, Adorea partim Utraque, partim Alterutra, Fautorum, Amicorum, Discipulorum, Gratulationibus, omnibus, votis, ornate [...], Vratislaviæ [1631], London, British Library, sygn. 11409.bb 50.

${ }^{58}$ Munposvvov Natali Quarto \& Sexagefimo [...] Dn. M. Elice Majoris. P. L. C. Gymnasii Elifabetani [...] dedicatum à Filio \& ejus quibufdam amantifsimis Difcipulis, Vratislaviæ 1651, BUWr, sygn. 444288.

59 Decus et Gloriam Musarum Vratislaviensium, Hoc est, Nobilem, Excellentissimum, Clarissimumque Virum M. Eliam Majorem, P.L.C. Gymnasii Vratislaviensium 
narracji z dyskursem z zakresu życia prywatnego wrocławskiego nauczyciela uznamy za cechę w jakiejś mierze humanistyczną, to podobny profil ujawnią jego Schreibkalender, zapisywane przez kolejne kilkadziesiąt lat życia. Źródła te pozwalają na jeszcze bogatsze ukazanie sylwetki Eliasa Maiora oraz pełniejszą interpretację jego dorobku literackiego i dydaktycznego. Zapiski te stanowią również bogatą i barwną dokumentację codziennej egzystencji rektora elżbietańskiego gimnazjum, toczącej się zarówno in publicis: w szkole, kościele i magistracie, jak i privatim: w domach przyjaciól, ich ogrodach oraz tawernach. Wyłaniający się stąd obraz przedstawię tu tylko w jednej z możliwych perspektyw, związanej z opisywanym przez Maiora „pejzażem dźwiękowym" nadodrzańskiej metropolii. Mam jednak nadzieję, że ta, niepełna ze swej natury, perspektywa przyniesie mimo wszystko satysfakcjonującą rekonstrukcję przeszłości, opisywanej tak ciekawie przez wykształconego muzycznie wrocławskiego humanistę.

Swoimi notatkami Elias Maior zapełniał kolejne woluminy kalendarzy, opracowanych przez Valentina Hanckego, a drukowanych w formacie $8^{\circ}(145 \times 90 \mathrm{~mm})$ przez wrocławską oficynę Georga Baumanna ${ }^{60}$. W kalendarzach tych wydawca podawat informacje o przypadających w kolejne dni roku świętach, zgromadzeniach publicznych i targach, nadto konstelacje astrologiczne, a czasem nawet wynikające z nich prognozy pogody. Jednak większą część kart typograf pozostawił pustą, przeznaczając je na zapiski korzystających zeń osób. Strony te Elias Maior bardzo systematycznie wykorzystywał, wpisując na nich niemal codziennie (od 1 I 1640 do 16 VI 1669) dość krótkie najczęściej i rzeczowe relacje. Zazwyczaj są to zapiski ze zdarzeń bezpośrednio dotyczących rektora Elisabetanum i spotkań odbytych we wrocławskich szkołach, kościołach oraz domach; czasami przywoływane są wydarzenia społeczne i polityczne, pojawiają się obserwacje

Elisabetani Rectorem Meritissimum. Pia admodum placidaque morte, Anno Chr. M DC LXIX. XVI. Cal Augusti Rebus terrestribus exemtum [...], Breslau 1669; J. L. Flood, op. cit., vol. 3, s. 1235.

60 Schreibkalender auffs das Jahr nach Chrifti Geburt [...] Mit Vermerckung etzlicher gewiffer Tage, an welchen das Fürften= oder Oberrecht, so wol das Königliche Mannrecht [...] Stadt=recht, Schöppenftube und Ferien bey Gerichten, die Groffe und Kleine Wollefchaar in der Kayfer= und Königlichen Stadt Breßlaw, pfleget gehalten zu werden. Allen Obrigkeiten, Doctorn, Cantzleyverwandten, Advocaten und Kauffleuten zu dienftlichem brauch Sonderlich zugerichtet [...]. Spośród 30 roczników kalendarzy zapisanych przez Maiora do naszych czasów zachował się 22 tomy, przechowywane obecnie w BUWr, Oddział Rękopisów, sygn. R 2339-R 2369. 
przyrodnicze i astronomiczne. Zdecydowana większość zapisków dotyczy jednak publicznej aktywności Maiora, wiążącej się z pełnionymi przezeń we Wrocławiu funkcjami dydaktycznymi: miejskiego inspektora szkolnego i rektora Gimnazjum św. Elżbiety.

Jako rektor tej placówki, Maior odpowiedzialny był przede wszystkim za sprawy osobowe i finanse. Systematycznie raz na kwartał odnotowywał rationes scholasticae należące się nauczycielom szkoły i wypłacane przezeń z kasy wrocławskiego magistratu. Rachunki te zdają sprawę z hierarchii społecznej wychowawców poszczególnych klas gimnazjów: najhojniej opłacani byli collegae primi ordinis - wychowawcy klasy najwyższej. Niektórzy nauczyciele pełnili jednocześnie funkcje muzyczne, jak np. Johann Balthasar Cargius, który w latach 1643-1686 był kantorem w kościele św. Elżbiety ${ }^{61}$, czy Daniel Sartorius, który w Elisabetanum najprawdopodobniej uczył m.in. muzyki ${ }^{62}$. Z zapisków Maiora wynika, że efekty nauczania muzyki były wykorzystywane nie tylko w szkole, ale także w kościele ${ }^{63}$. Praktykę łączenia stanowisk nauczycielskich i kościelnych umożliwiały instytucjonalne i personalne związki między parafią a działającą przy niej szkołą ${ }^{64}$. Zjawisko to dokumentują zresztą kolejne Schulordnungen Gimnazjum św. Elżbiety: wszak spośród jej wychowanków rekrutowano muzyków do zespołu Chorknaben, śpiewającego w kościele pod tym samym wezwaniem.

Z wyróżniających się uczniów klas starszych gimnazjum, pełniących w szkole funkcję nauczycieli-stażystów, składał się z kolei profesjonalny zespół choralistów (Choralisten) ${ }^{65}$. Ze względu na przysługujące jego członkom deputaty z budżetu miasta ich przełożonym był miejski inspektor szkolny. Odpowiadał on za stan osobowy zespołu:

${ }^{61}$ BUWr, sygn. R 2347, k. 24rec. [13 II 1648]; R. Starke, Kantoren und Organisten der St. Elisabethkirche zu Breslau, „Monatshefte für Musikgeschichte”, 35, 1903, nr 3, s. 41-48.

${ }^{62}$ BUWr, sygn. R 2343, k. 59rec. [14 XII 1644]; R 2347, k. 142rec. [7 X 1648]; R 2348, k. 79rec. [7 VI 1649]; R 2349, k. 29rec. [23 II 1650] itd.; por. T. Jeż, The Italian Music Collection of Daniel Sartorius from Breslau, w: Music Migration in the Early Modern Age. Centres and Peripheries - People, Works, Styles, Paths of Dissemination and Influence, eds. by J. Guzy-Pasiak, A. Markuszewska, Warszawa 2016, s. 171-182.

${ }^{63}$ BUWr, sygn. R 2342, k. 65rec. [8 V 1643]; R 2348, k. 102rec. [23 VII 1649]; R 2349, k. 98rec. [11 VII 1650].

${ }^{64}$ G. Bauch, Geschichte des Breslauer Schulwesens, s. 339-342.

65 J. Sass, op. cit., s. 13-14, 30, 33-39. 
przyjmował do niego nowych członków ${ }^{66}$, nominował przełożonych (zwanych sygnatorami), wypłacał rodzinom zmarłych choralistów odszkodowanie ${ }^{67}$, podejmował wobec nich sankcje dyscyplinarne, np. kilkunastogodzinny areszt w karcerze (skazywał nań za bójki, kradzieże i pijatyki ${ }^{68}$. Podobna kara groziła choralistom podejmujących bez zgody przełożonych zlecenia muzyczne $w$ innych kościolach miasta i zaniedbujących przy tym swoje obowiązki w macierzystej parafii ${ }^{69}$. Elias Maior zobowiązany był nadto wyciągać dyscyplinarne konsekwencje wobec młodszych uczniów gimnazjum, na których hałásiwe zachowanie często skarżyli się wrocławscy mieszczanie $^{70}$.

Znacznie przyjemniejszym obowiąziem rektora Elisabetanum było przyjmowanie egzaminów szkolnych, odbywających się we wszystkich klasach gimnazjum dwa razy do roku: na przełomie kwietnia i maja oraz $\mathrm{w}$ połowie października ${ }^{71}$. Uczniowie egzaminowanych klas popisywali się przed rektorem łacińskimi deklamacjami, a ich teksty czerpano z ód Horacego, eklog Wergiliusza, komedii Terencjusza i dialogów Erazma ${ }^{72}$. Przedstawieniom towarzyszyła prawdopodobnie oprawa muzyczna, co może sugerować odnotowywana przez Maiora częsta obecność podczas tych egzaminów takich

${ }^{66}$ Do zespołu choralistów kościoła św. Elżbiety przez Eliasa Maiora przyjęci byli m.in. Matthias Reichenavius - BUWr, sygn. R 2342, k. 22rec. [11 II 1643], Daniel Hempelius - BUWr, sygn. R 2345, k. 169ver. [1 XII 1646], Balthasar Hell - BUWr, sygn. R 2346, k. 69ver. [15 V 1647], Christianus Agricola BUWr, sygn. R 2347, k. 104rec. [24 VII 1648], David Buchs - BUWr, sygn. R 2348, k. 67ver. [15 V 1649] i Martinus Reichel - BUWr, sygn. R 2366, k. 176ver. [15 XII 1667].

${ }^{67}$ BUWr, sygn. R 2357, k. 82rec. [9 VI 1658].

${ }^{68}$ Daniel Thomas - BUWr, sygn. R 2343, k. 62ver. [7 XII 1644]; Matthias Rechenovius - BUWr, sygn. R 2344, k. 135rec. [25 IX 1645]; Nicolaus Maul - BUWr, sygn. R 2345, k. 122ver. [29 VIII 1646]; Christoph Stollius - BUWr, sygn. R 2357, k. 163ver. [19 XI 1658]; Sigmundus Arnoldus - BUWr, sygn. R 2358, k. 4ver. [9 I 1659].

${ }^{69}$ BUWr, sygn. R 2347, k. 141 rec. [5 X 1648]: „N. Agricola Choralis, quo heri in aede Dorothea ubi festum Francisci celebrabatur. Musicam adjuvent et officium suum in choro Elisabetano neglexerunt, jussu Dn. D An. Weberi, carceri scholastici, includitur".

${ }^{70}$ M. Hippe, op. cit., s. 168.

${ }^{71}$ L. Noack, op. cit., s. 231-235.

72 BUWr, sygn. R 2348, k. 145ver. [20 X 1649]; R 2350, k. 60rec. [26 IV 1651]; R 2354, k. 51ver. [13 IV 1655]; R 2354, k. 154rec. [4 XI 1655]; R 2355, k. 63ver. [3 V 1656]. 
nauczycieli jak Johann Balthasar Cargius czy Daniel Sartorius ${ }^{73}$. Przekonuje zaś o tym wspomniana już Schulordnung z roku 1643, w której nie tylko ustalono długość i częstość odbywania actus scholastici we wrocławskich gimnazjach, ale także określono sposób dofinansowywania ex publico wydatków na muzykę, ponoszonych przy okazji wystawiania tych spektakli ${ }^{74}$. $\mathrm{Na}$ obecność muzyki podczas przedstawień wskazują też te zapiski Maiora, w których nadmienia on o wplataniu w scenariusz spektakli konkretnych utworów ${ }^{75}$, wzbogacaniu ich przez muzykę ${ }^{76}$, wykonywaną z towarzyszeniem instrumentów szczególnie wtedy, gdy wymagała tego treść spektaklu ${ }^{77}$.

Dynamiczny rozwój teatru szkolnego we Wrocławiu stymulowała również konkurencja z jezuickim dramatem szkolnym, który od lat czterdziestych XVII w. rozwijał się bujnie w tym mieście ${ }^{78}$. Na pierwszych kilku przedstawieniach zorganizowanych przez jezuitów, odbywających się we wrocławskim zamku i w klasztorze św. Macieja, Elias Maior pojawił się nawet osobiście ${ }^{79}$, na kolejne jednak - mimo ponawianych zaproszeń ze strony jezuitów - już nie przychodził. Nie pozwalał też na nie uczęszczać swoim uczniom ${ }^{80}$, niektórzy z nich bowiem po takich spektaklach decydowali się na konwersję na katolicyzm... ${ }^{81}$ Nasilający się w mieście konflikt konfesyjny nie przeszkodził jednak we wzajemnym inspirowaniu się obydwu środowisk zarówno wykorzystywaną w spektaklach tematyką, jak i towarzyszącą przedstawieniom oprawą muzyczną ${ }^{82}$. Dotyczyło to zresztą nie tylko klasycznego

${ }^{73}$ Na przykład: BUWr, sygn. R 2342, k. 143ver. [14 X 1643]; R 2343, k. 33ver. [13 X 1644]; R 2354, k. 142ver. [12 X 1655].

${ }^{74}$ M. Hippe, op. cit., s. $176-177$.

${ }^{75}$ BUWr, sygn. R 2343, k. 63r [8 XII 1644]: „Actus a me institutus, habetur [- - ] Beati Dn Apellis Cantilena, Weiche Mars etc. tota sed per partes tres, Germanice decantata, Latini autem a duobus pueris recitata est".

${ }^{76}$ BUWr, sygn. R 2339, k. 38rec. [13 III 1640]: „A prandio Actus scholasticus [- - ] habitus est [- ] Musica sonuit omnio instrumentalis, citra humanam vocem”.

77 BUWr, sygn. R 2355, k. 130ver. [14 IX 1656]: „Actus pomposis a Kleinwechter institutus, De Musica, habetur. Adhibita sunt Instrumenta Musica pleraque omnia”.

${ }^{78}$ L. Noack, op. cit., s. 236-242; T. Jeż, Kultura muzyczna jezuitów na Ślasku i ziemi ktodzkiej (1581-1776), Warszawa 2013, s. 312-378.

${ }^{79}$ BUWr, sygn. R 2339, k. 139ver. [2 X 1640]; R 2342, k. 139ver. [6 X 1643].

${ }^{80}$ M. Hippe, op. cit., s. 180.

${ }^{81}$ R. J. Alexander, Zum Jesuitentheater in Schlesien. Eine Übersicht, w: Funde und Befunde zur schlesischen Theatergeschichte, I., Dortmund 1983, s. 56.

82 J. Budzyński, Dramat i teatr szkolny na Ślasku (XVI-XVIII wiek), Katowice 1996, s. 25. 
dramatu szkolnego, ale i wystawianych przez obydwie konfesje spektakli pasyjnych; wiadomo, że actus passionales inscenizowane w Wielki Piątek przez uczniów Gimnazjum św. Marii Magdaleny cieszyły się rokrocznie obecnością rektora Elisabetanum ${ }^{83}$.

Poza spektaklami szkolnymi i religijnymi wrocławskie gimnazja protestanckie były w czasach Maiora także miejscem kultywowania teatru niemieckojęzycznego. Ale nawet jeśli wybór języka niemieckiego jako głównego medium teatru szkolnego uznamy za ucieczkę od konkurencji z jezuitami w dziedzinie dramatu łacińskiego, to przyniosła ona wrocławskim ewangelikom bardzo dobre wyniki, naśladowane zresztą później przez ich konfesyjnych konkurentów... To właśnie administrowane przez Eliasa Maiora gimnazja dały premiery spektakli Martina Opitza (Judith, wystawiana z muzyką Mattheusa Apellesa von Löwensterna), Andreasa Gryphiusa (Cardenio und Celinde, Felicitas, Papinianus) czy Daniela Caspara von Lohensteina (Agrippina, Cleopatra, Epicharis, Sophonisbe) - autorów tworzących kanon nowożytnego dramatu niemieckiego ${ }^{84}$. O muzycznej warstwie tych arcydzieł świadczą informacje pochodzące $\mathrm{z}$ zachowanych sumariuszy spektakli teatralnych inscenizowanych przez Maiora ${ }^{85}$ i pewne wzmianki w jego pamiętnikach ${ }^{86}$. Uwagi na temat tych spektakli są niestety dość ogólnikowe, być może dlatego, że Maior znał te utwory jeszcze przed wykonaniem: jako inspektor szkolny opiniował je bowiem jako odpowiednie dla scen wrocławskich gimnazjów.

Ważnym miejscem aktywności Eliasa Maiora był sąsiadujący z gimnazjum kościół św. Elżbiety. Liczne w jego pamiętnikach adnotacje na temat życia muzycznego tej świątyni zawdzięczamy nie tylko pobożności rektora, lecz również wspomnianym już związkom instytucjonalnym, łączącym szkołę z poświęconym tej samej patronce

${ }^{83}$ BUWr, sygn. R 2344, k. 53rec. [14 IV 1645]; R 2346, k. 56ver. [19 IV 1647]; R 2348, k. 47 [2 IV 1649] itd.

${ }^{84}$ K. Garber, op. cit., s. 322-338; Das Breslauer Schultheater im 17. und 18. Jahrbundert. Einladungsschriften zu den Schulactus und Szenare zu den Aufführungen förmlicher Comödien an den protestantischen Gymnasien, hrsg. von K. Gajek, Tübingen 1994.

${ }^{85}$ Que res nobis, omnibusque Crucifixum Dominum amantibus, profpere eveniat! Veram Vitem Ejusque; Proprietates \& Folia in Paffionali Gymnasii Vratislavienfis Elifabetani actû A. D. IV. Calend. Aprileis, CID IDC XLII. Pie contemplanda indicit M. Elias Major Rector, Breslæ 1642, Berlin, Staatsbibliothek Preußischer Kulturbesitz, sygn. Ah 16124/20. W programie tego spektaklu znajduje się uwaga: Ex Germanica quidem cantione, Da Jesus an dem Creutze stund, Greco carmine.

${ }^{86}$ M. Hippe, op. cit., s. 178. 
kościołem. Każdy rok w kalendarzach Maiora rozpoczynały informacje na temat strena musica, dystrybuowanych (zapewne przez samego rektora) w pierwszych dniach stycznia muzykom kościoła św. Elżbiety: kantorowi, sygnatorowi i jego zastępcy (subsygnatorowi), choralistom oraz niewymienionym z nazwiska dyszkantystom. Podane przez Maiora wykazy uzupełniają znaną dziś dokumentację osobową zespołu muzycznego wrocławskiej fary ${ }^{87}$ o wiele nowych danych. Przytaczam je na następnych stronach $\mathrm{w}$ formie tabeli.

Wymienieni wyżej muzycy zajmowali się oprawą muzyczną liturgii $\mathrm{w}$ kościele św. Elżbiety oraz $\mathrm{w}$ podporządkowanym mu kościele filialnym św. Barbary. W swoich zapiskach Elias Maior odnotowywał swoją obecność w tych kościołach na najważniejszych nabożeństwach, np. w Wielki Czwartek, kiedy to liturgię sacrae synaxis zdobiła musica harmonica in choro, vocalis et instrumentalis ${ }^{8}$. Wykonaniami tymi kierował zwykle kantor, Johann Balthasar Cargius ${ }^{89}$, a w przypadku jego nieobecności - sygnator Caspar Seifert ${ }^{90}$. Na nabożeństwach w kościele Maior bywał oczywiście częściej; miał przy tym zwyczaj sporządzać konspekty kazań wygłaszanych przez pastorów, szczególnie przez Jana Akoluta (1628-1689), jego dawnego ucznia z Elisabetanum, a później następcy na stanowisku inspektora szkolnego we Wrocławiu ${ }^{91}$. Zanim jednak ten znany autor pieśni i wydawca Doskonatego kancjonatu polskiego (Brzeg 1673) został powołany na eklezjastę kościoła św. Elżbiety, Maior zapisywał w pamiętniku tytuły śpiewanych w tym kościele przed kazaniami pieśni: Verleih uns die Zeiten gut ${ }^{92}$, Christ der uns selig macht ${ }^{93}$, Du Friedensfürst, Herr Jesu Christ ${ }^{94}$, Nun last uns Gott der Herre ${ }^{95}$. W jednym przypadku wrocławski rektor wymienił kompozytora opracowania melodii

${ }^{87}$ Por. T. Jeż, Z przeszłości muzycznej wroctawskiego kościoła św. Elżbiety w czasach baroku, „Muzyka. Kwartalnik Instytutu Sztuki Polskiej Akademii Nauk”, 52, 2007, nr 4, s. 83-111.

${ }^{88}$ BUWr, sygn. R 2368, k. 56rec. [18 IV 1669].

${ }^{89}$ BUWr, sygn. R 2357, k. 56rec. [28 IV 1658].

90 BUWr, sygn. R 2342, k. 47rec. [2 IV 1643]; R 2354, k. 42rec. [25 III 1655].

${ }^{91}$ BUWr, sygn. R 2363, k. 52ver. [11 IV 1664]; R 2363, k. 113rec. [10 VIII 1664]; R 2363, k. 157ver. [7 XI 1664] itd.; por. A. Rombowski, Wydawcy Wielkiego Kancjonatu Wroctawskiego z roku 1673, „Pamiętnik Literacki”, 45, 1954, nr 3, s. 212-234.

92 BUWr, sygn. R 2345, k. 128rec. [9 IX 1646].

93 BUWr, sygn. R 2346, k. 48rec. [3 IV 1647].

${ }^{94}$ BUWr, sygn. R 2347, k. 125ver. [4 IX 1648].

${ }^{95}$ BUWr, sygn. R 2354, k. 89rec. [27 VI 1655]. 
Tabela 1. Noworoczne strena musica dla muzyków kościoła św. Elżbiety we Wrocławiu (kwoty w talarach cesarskich i srebrnych groszach)

\begin{tabular}{|c|c|c|c|c|c|c|c|c|c|}
\hline Źródło [data] & \multicolumn{2}{|l|}{ Kantor } & \multicolumn{2}{|c|}{ Sygnator } & \multicolumn{2}{|l|}{ Subsygnator } & \multicolumn{2}{|l|}{ Choraliści } & $\begin{array}{l}\text { Duos pueris } \\
\text { discantistos }\end{array}$ \\
\hline \multirow{3}{*}{$\begin{array}{l}\text { R 2342, fol. 8ver. } \\
\text { [15 I 1643] }\end{array}$} & \multirow[t]{3}{*}{ Godefridus Wagner } & \multirow[t]{3}{*}{72} & \multirow[t]{3}{*}{ Caspar Seifert } & \multirow[t]{3}{*}{27} & \multirow[t]{2}{*}{ Johannes Mauritius } & \multirow[t]{2}{*}{12} & David Bassista & 17 & \multirow[t]{3}{*}{2} \\
\hline & & & & & & & Tres aliis choralibus & 36 & \\
\hline & & & & & Michael Weber & 10 & Johannes Grunder & nulla & \\
\hline \multirow{2}{*}{$\begin{array}{l}\text { R 2344, fol. 8rec. } \\
\text { [12 I 1645] }\end{array}$} & \multirow[t]{2}{*}{ Johann Balthasar Cargius } & \multirow[t]{2}{*}{64,12} & \multirow[t]{2}{*}{ Caspar Seifert } & \multirow[t]{2}{*}{34,6} & David Malchovius & 3,6 & Tribus aliis choralibus & 34 & \multirow[t]{2}{*}{2} \\
\hline & & & & & Henricus Pretius & 14,3 & Duobus novitii & 17,3 & \\
\hline \multirow{6}{*}{$\begin{array}{l}\text { R 2345, fol. 7rec. } \\
\text { [19 I 1646] }\end{array}$} & \multirow[t]{6}{*}{ Johann Balthasar Cargius } & \multirow[t]{6}{*}{$64^{1 / 2}$} & \multirow[t]{6}{*}{ Caspar Seifert } & \multirow[t]{6}{*}{$32 \frac{1}{2}$} & \multirow[t]{6}{*}{ Henricus Nentwig } & \multirow[t]{6}{*}{$15^{1 / 2}$} & Matthias Reichenavius & $103 / 4$ & \multirow[t]{6}{*}{2} \\
\hline & & & & & & & Maul & $103 / 4$ & \\
\hline & & & & & & & Christianus & 8 & \\
\hline & & & & & & & Trimler & $63 / 4$ & \\
\hline & & & & & & & Tscherning & $53 / 4$ & \\
\hline & & & & & & & Bartholomeus & $53 / 4$ & \\
\hline \multirow{6}{*}{$\begin{array}{l}\text { R 2346, fol. 6ver. } \\
\text { [9 I 1647] }\end{array}$} & \multirow[t]{6}{*}{ Johann Balthasar Cargius } & \multirow[t]{6}{*}{68} & \multirow[t]{6}{*}{ Caspar Seifert } & \multirow[t]{6}{*}{34} & \multirow[t]{6}{*}{ Henricus Praetorius } & \multirow[t]{6}{*}{14,10} & Maul & 11,10 & \multirow[t]{6}{*}{2} \\
\hline & & & & & & & Tscherning & 11,10 & \\
\hline & & & & & & & Gresner & 5 & \\
\hline & & & & & & & Bock & 5 & \\
\hline & & & & & & & Isaac & 4 & \\
\hline & & & & & & & Daniel & 1 & \\
\hline R 2347, fol. 10rec. & Johann Balthasar Cargius & 52 & Caspar Seifert & 26 & Henricus Praetorius & 12 & Quatuor Chorales & $\begin{array}{r}4 x \\
81 / 2 \\
\end{array}$ & 2 \\
\hline & & & & & & & Duo Chorales & $\begin{aligned} 2 x \\
61 / 2\end{aligned}$ & \\
\hline
\end{tabular}




\begin{tabular}{|c|c|c|c|c|c|c|c|c|c|}
\hline Źródło [data] & \multicolumn{2}{|l|}{ Kantor } & \multicolumn{2}{|c|}{ Sygnator } & \multicolumn{2}{|l|}{ Subsygnator } & \multicolumn{2}{|l|}{ Choraliści } & $\begin{array}{l}\text { Duos pueris } \\
\text { discantistos }\end{array}$ \\
\hline \multirow{2}{*}{$\begin{array}{l}\text { R 2348, fol. 8ver. } \\
\text { [13 I 1649] }\end{array}$} & Johann Balthasar Cargius & 41,12 & \multirow{2}{*}{ Caspar Seifert } & \multirow[t]{2}{*}{23,21} & \multirow[t]{2}{*}{ Henricus Praetorius } & \multirow[t]{2}{*}{10,5} & \multirow[t]{2}{*}{ Agricola } & \multirow[t]{2}{*}{4} & \multirow[t]{2}{*}{2} \\
\hline & \begin{tabular}{|l|} 
David Meisner \\
\end{tabular} & 2 & & & & & & & \\
\hline \multirow{4}{*}{$\begin{array}{l}\text { R 2349, fol. 11ver. } \\
\text { [19 I 1650] }\end{array}$} & \multirow[t]{4}{*}{ Johann Balthasar Cargius } & \multirow[t]{4}{*}{54} & \multirow[t]{4}{*}{ Caspar Seifert } & \multirow[t]{4}{*}{27} & \multirow[t]{4}{*}{ David Buchs } & \multirow[t]{4}{*}{11} & Tres chorales & 27 & \multirow[t]{4}{*}{2} \\
\hline & & & & & & & \begin{tabular}{|l|} 
Ficker \\
\end{tabular} & 7 & \\
\hline & & & & & & & Lerche & 5 & \\
\hline & & & & & & & David Meisner & 1 & \\
\hline \multirow{5}{*}{$\begin{array}{l}\text { R 2350, fol. 7ver. } \\
\text { [11 I 1651] }\end{array}$} & \multirow[t]{5}{*}{ Johann Balthasar Cargius } & \multirow[t]{5}{*}{53} & \multirow[t]{5}{*}{ Caspar Seifert } & \multirow[t]{5}{*}{26,15} & \multirow[t]{5}{*}{ David Buchs } & \multirow[t]{5}{*}{11,10} & Tres Chorales & $\begin{array}{r}3 \times \\
8,25 \\
\end{array}$ & \multirow[t]{5}{*}{2} \\
\hline & & & & & & & Munche & 5 & \\
\hline & & & & & & & Ungarus & 4 & \\
\hline & & & & & & & Georg Seidel & 1,15 & \\
\hline & & & & & & & \begin{tabular}{|l|} 
David Meisner \\
\end{tabular} & 1 & \\
\hline \multirow{4}{*}{$\begin{array}{l}\text { R 2354, fol. 7ver. } \\
\text { [15 I 1655] }\end{array}$} & \multirow[t]{4}{*}{ Johann Balthasar Cargius } & \multirow[t]{4}{*}{50,20} & \multirow[t]{4}{*}{ Caspar Seifert } & \multirow[t]{4}{*}{25,10} & \multirow[t]{4}{*}{ David Buchs } & 10,15 & Trium Choralium & $\begin{array}{r}3 \times \\
4,10 \\
\end{array}$ & - \\
\hline & & & & & & & N.N. & 5,20 & \\
\hline & & & & & & & N.N. & 4,6 & \\
\hline & & & & & & & N.N. & 2,10 & \\
\hline $\begin{array}{l}\text { R 2355, fol. 10ver. } \\
\text { [17 I 1656] }\end{array}$ & Johann Balthasar Cargius & $52 \frac{1}{1 / 2}$ & Caspar Seifert & $26^{1 / 4}$ & David Buchs & $113 / 4$ & Quatuor Choralium & $\begin{array}{r}4 \times \\
83 / 4 \\
\end{array}$ & - \\
\hline & & & & & & & Rettig & $41 / 4$ & \\
\hline & & & & & & & Guttermath & 1 & \\
\hline R 2356, fol. 10rec. & Johann Balthasar Cargius & $52 \frac{1}{2}$ & Caspar Seifert & $26^{1 / 4}$ & David Buchs & $10^{1 / 2}$ & Choralium & $\begin{array}{r}5 \times \\
4,21 \\
\end{array}$ & - \\
\hline [16 I 1657] & & & & & & & Ultimus Choralis & $11 / 2$ & \\
\hline
\end{tabular}




\begin{tabular}{|c|c|c|c|c|c|c|c|c|c|}
\hline Źródło [data] & \multicolumn{2}{|l|}{ Kantor } & \multicolumn{2}{|c|}{ Sygnator } & \multicolumn{2}{|l|}{ Subsygnator } & \multicolumn{2}{|c|}{ Choraliści } & $\begin{array}{l}\text { Duos pueris } \\
\text { discantistos }\end{array}$ \\
\hline \multirow{3}{*}{$\begin{array}{l}\text { R 2357, fol. 12ver. } \\
\text { [21 I 1658] }\end{array}$} & \multirow[t]{3}{*}{ Johann Balthasar Cargius } & \multirow[t]{3}{*}{50} & \multirow[t]{3}{*}{ Caspar Seifert } & \multirow[t]{3}{*}{25} & \multirow[t]{3}{*}{ David Buchs } & \multirow[t]{3}{*}{10,12} & Duo chorales & 8 & \multirow[t]{3}{*}{-} \\
\hline & & & & & & & Duo chorales & 4 & \\
\hline & & & & & & & Duo chorales & 2 & \\
\hline \multirow{2}{*}{$\begin{array}{l}\text { R 2363, fol. } 7 \\
{[10 \text { I 1664] }} \\
\end{array}$} & \multirow[t]{2}{*}{ Johann Balthasar Cargius } & \multirow[t]{2}{*}{52} & \multirow[t]{2}{*}{ David Buchs } & \multirow[t]{2}{*}{26} & David Buchs & 1 & \multirow{2}{*}{ Quatuor chorales } & \multirow{2}{*}{$\begin{array}{r}4 \times \\
4,20\end{array}$} & \multirow[t]{2}{*}{-} \\
\hline & & & & & Clapius & 4,20 & & & \\
\hline \multirow{6}{*}{$\begin{array}{l}\text { R 2366, fol. 8ver. } \\
\text { [13 I 1667] }\end{array}$} & \multirow{6}{*}{ Johann Balthasar Cargius } & \multirow[t]{6}{*}{54} & \multirow[t]{6}{*}{ David Buchs } & \multirow[t]{6}{*}{27} & \multirow[t]{6}{*}{ Andreas Reichwald } & \multirow[t]{6}{*}{11} & Johann Grünwald & 9 & \multirow[t]{6}{*}{-} \\
\hline & & & & & & & Georgius Fidicinis & 9 & \\
\hline & & & & & & & Frid. Neugebaur & 9 & \\
\hline & & & & & & & Christoph Schmid & 4 & \\
\hline & & & & & & & Joachim Klöpfel & 4 & \\
\hline & & & & & & & Johan Lörber & 3 & \\
\hline \multirow{5}{*}{$\begin{array}{l}\text { R 2368, fol. } 7 \\
{[8 \text { I 1669] }}\end{array}$} & \multirow[t]{5}{*}{ Johann Balthasar Cargius } & \multirow[t]{5}{*}{49,14} & \multirow[t]{5}{*}{ David Buchs } & \multirow[t]{5}{*}{24,24} & \multirow[t]{5}{*}{ Andreeas Reichwald } & \multirow[t]{5}{*}{10,2} & Christoph Hispind & 4,4 & \multirow[t]{5}{*}{-} \\
\hline & & & & & & & \begin{tabular}{|l|} 
Joachim Valentin \\
Klopsche \\
\end{tabular} & 4,4 & \\
\hline & & & & & & & Johannes Lerber & 4,4 & \\
\hline & & & & & & & \begin{tabular}{|l} 
Christoph Georg \\
Fischer \\
\end{tabular} & 4,4 & \\
\hline & & & & & & & Martinus Reichel & 4,4 & \\
\hline
\end{tabular}

Źródło: oprac. na podstawie pamiętników Eliasa Maiora. 
chorałowej $^{96}, \mathrm{w}$ innym zaś zamieścił w kalendarzu nuty pieśni śpiewanej zamiast zwyczajowej Wenn wir in höchsten Nöten sein:

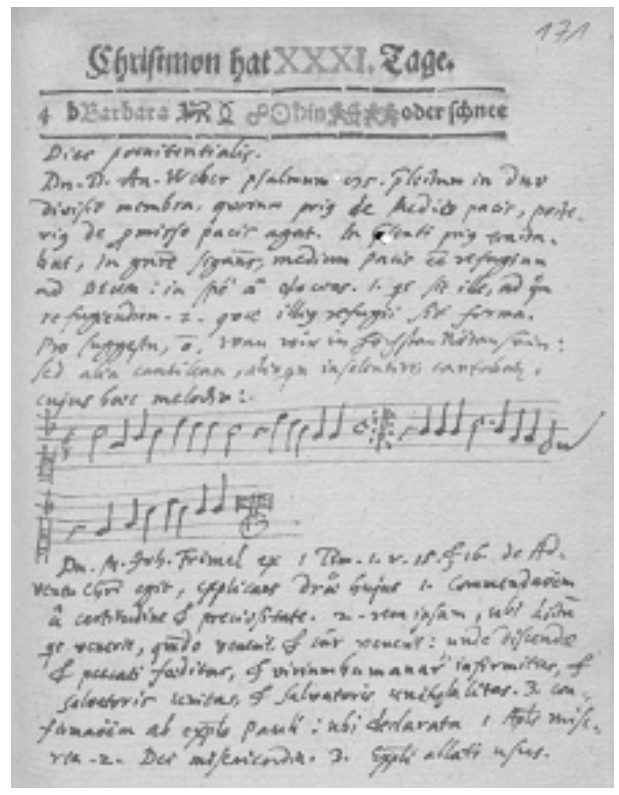

Il. 2. BUWr, Oddział Rękopisów, R 2347, fol. 171r (4 XII 1648)

Muzyka towarzyszyła także wyjątkowej rangi uroczystościom lokalnym, takim jak instalacja we wrocławskim kościele św. Elżbiety Jana Akoluta $^{97}$ czy też jego poprzednika na urzędzie eklezjastyka - Ananiasa Webera ${ }^{98}$. W obydwu przypadkach zespołem muzycznym kierował kantor Cargius; zdarzało się jednak, że oprawę muzyczną tego typu uroczystości prowadził organista z towarzyszącymi mu muzykami ${ }^{99}$. Elias Maior brał też udział w nabożeństwach pogrzebowych

${ }^{96}$ BUWr, sygn. R 2346, k. 120ver. [25 VIII 1647]: „Ultima cantilena fuit Verleih uns Frieden gnädeglich \&c. utiquidem numeris Musicis accomodavit Hammerschmidius: ubi, Gib unserem fürsten, und aller Obrigkeit, canebatur".

97 BUWr, sygn. R 2366, k. 75rec. [26 V 1667]: „Musica in choro, omnes alia in organo maiore, sonuit".

98 BUWr, sygn. R 2342, k. 64ver. [7 V 1643]: „Sonuit musica in choro Harmonica, instituente Dn Joh. Balth. Cargio Cantore”.

99 BUWr, sygn. R 2340, k. 153rec. [31 X 1641]: „Introductoria a Dn. M. Johann Fechnero habita. Adfuere propter ceteros virgulares, ipsi senatores decem. Musicam adornavit Dn. Ambrosius Profius, cui \& eius Adjuvantibus Gravitate trium Infirmicos ingalium datum". 
sprawowanych u św. Elżbiety, np. w intencji kantora tego kościoła Gottfrieda Wagnera ${ }^{100}$, sygnatora kościoła św. Marii Magdaleny Christiana Sagittariusa ${ }^{101}$, wrocławskiego kompozytora Mattheusa Apellesa von Löwensterna ${ }^{102}$ czy sygnatora kościoła św. Elżbiety Caspara Seiferta (jego pogrzebowi towarzyszyła nadzwyczajnie bogata oprawa muzyczna $)^{103}$. Szczególnie uroczysta muzyka - oczywiście o diametralnie odmiennym wyrazie - uświetniała też obchodzone we Wrocławiu koronacje cesarzy ${ }^{104}$ i ogłaszane przez nich pokoje, z których cieszono się śpiewanym w kościołach hymnem Te Deum laudamus, a z wież miasta rozbrzmiewała muzyka wokalna i instrumentalna ${ }^{105}$. Nieco mniej hucznie, choć równie uroczyście, świętowano rozpoczęcie roku szkolnego: sprawowanemu z tej okazji nabożeństwu towarzyszyła musica harmonica $\mathrm{z}$ towarzyszeniem wielkich organów ${ }^{106}$.

W pamiętnikach Elias Maior ujawnia też sporo informacji o swoim życiu prywatnym i miejscu w nim muzyki. Nie mogły się zapewne bez niej obyć wesela świętowane w domach jego współpracowników i przyjaciól: Johanna Balthasara Cargiusa ${ }^{107}$, Andreasa Eccarda ${ }^{108}$, Johannesa Gebharda ${ }^{109}$ i Ambrosiusa Profego ${ }^{110}$. O muzyce Maior wspomina jednak znacznie częściej przy takich okazjach jak jego własne imieniny, obchodzone 20 lipca bądź kilka dni później. Celebrował je zwykle ze swoimi przyjaciółmi, „cum vino et carminibus”"111: chodziło tu jednak nie tylko o pieśni, ale i może bardziej wyszukany repertuar, skoro kilka razy odnotował: „sonuit vocalis \& instrumentalis musica” ${ }^{112}$,

${ }^{100}$ BUWr, sygn. R 2342, k. 12ver. [23 I 1643]; R 2342, k. 14ver. [27 I 1643].

101 BUWr, sygn. R 2347, k. 10ver. [17 I 1648].

102 BUWr, sygn. R 2347, k. 60rec. [26 IV 1648].

${ }^{103}$ BUWr, sygn. R 2357, k. 84rec. [13 VI 1658]: „In turri curiali tubae \& tympana sonuere. In turribus Elisabetana \& Magdalanea, Musica instrumentalis \& vocalis sonitu".

${ }^{104}$ BUWr, sygn. R 2355, k. 139rec. [1 X 1656]; R 2356, k. 29rec. [25 II 1657]; R 2357, k. 112ver. [11 VIII 1658].

${ }^{105}$ BUWr, sygn. R 2346, k. 93ver. [2 VII 1647]; R 2347, k. 108rec. [25 X 1648]; R 2349, k. 104ver. [24 VII 1650]; R 2363, k. 176 [14 XII 1664].

106 BUWr, sygn. R 2339, k. 140rec. [3 X 1640]; R 2341, k. 140rec. [3 X 1642]; R 2356, k. 140rec. [5 X 1657]; R 2357, k. 140ver. [ 4 X 1658]; R 2358, k. 138rec. [3 X 1659]; R 2366, k. 138rec. [29 IX 1667].

107 BUWr, sygn. R 2343, k. 55ver. [29 XI 1644].

${ }_{108}$ BUWr, sygn. R 2344, k. 62rec. [2 V 1645].

109 BUWr, sygn. R 2344, k. 167rec. [28 XI 1645].

110 BUWr, sygn. R 2347, k. 155ver. [3 XI 1648].

111 BUWr, sygn. R 2339, k. 102ver. [20 VII 1640].

112 BUWr, sygn. R 2339, k. 103ver. [22 VII 1640]; R 2342, k. 100ver. [20 VII 1643]. 
tylko jeden raz określona jako mediocris ${ }^{113}$. Gośćmi Maiora bywali wymieniani z nazwiska nauczyciele z Elisabetanum, organista Ambrosius Profe i jego dzieci wraz z małżonkami ${ }^{114}$. Czasami zapraszano także jego uczniów z gimnazjum, którzy „musicam instrumentali \& vocali [--] Nominalem diem honorare voleruent" ${ }^{115}$. Kilka razy Maior zanotował, że wykonywali oni przy tej okazji repertuar specjalnie dla niego skomponowany, a czasami nawet wydany drukiem na tę okolicznośćl16.

Okoliczności do wykonywania muzyki stwarzały także imieniny Ambrosiusa Profego, który co roku 4 kwietnia zapraszał szwagra do swego domu na obiad lub kolację. Gdy gości było więcej, Maior odnotowywał zabawę młodzieży przy muzyce i tańcach ${ }^{117}$, znacznie częściej jednak wspominał pite przy tych okazjach wino ${ }^{118}$, a także spożywane wtedy dania $\mathrm{z}$ ryb ${ }^{119}$ i pierniki ${ }^{120}$. Elżbietański organista był bliskim przyjacielem Maiora: w jego pamiętnikach wzmianki o wspólnych z Profem posiłkach pojawiają się zdecydowanie najczęściej, nawet kilkanaście razy do roku. O wzajemnych relacjach obu przyjaciół świadczą również wspólnie odbywane balneae domesticae ${ }^{121}$, praktyczna pomoc okazywana przez Maiora Profemu po jego wypadku ${ }^{122}$ i mediacja elżbietańskiego rektora w rozwiązaniu dość kłopotliwej dla organisty sprawy jego córki Marii, która uparła się, że wyjdzie za mąż za katolika Christopha Wildenhaina ${ }^{123}$. Sam Maior ze swymi dziećmi większych kłopotów chyba nie miał, chociaż nie wiemy, dlaczego Casparus Citharedeus zatrudniony do uczenia gry na skrzypcach jego córki Rosiny już po dwóch miesiącach został odprawiony... ${ }^{124}$

113 BUWr, sygn. R 2344, k. 101ver. [20 VII 1645].

${ }^{114}$ BUWr, sygn. R 2345, k. 103ver. [22 VII 1646]; R 2346, k. 103ver. [22 VII 1647]; R 2348, k. 101ver. [22 VII 1649] itd.

115 BUWr, sygn. R 2355, k. 102ver. [20 VII 1656].

116 BUWr, sygn. R 2358, k. 100rec. [20 VII 1659]; R 2358, k. 100ver. [20 VII 1659].

117 BUWr, sygn. R 2345, k. 49rec. [4 IV 1646].

${ }^{118}$ BUWr, sygn. R 2347, k. 49rec. [4 IV 1648]; R 2349, k. 49rec. [3 IV 1650]; R 2350, k. 49rec. [4 IV 1651] itp.

${ }_{119}$ BUWr, sygn. R 2354, k. 57rec. [4 IV 1655]; R 2356, k. 48 [4 IV 1657].

${ }^{120}$ BUWr, sygn. R 2344, k. 48rec. [4 IV 1645]: „Nominalem Dn. Ambr. Profii vino \& paucis tabellis panis melleopiperati celebratum".

${ }^{121}$ BUWr, sygn. R 2342, k. 46rec. [31 III 1643]; R 2342, k. 89rec. [27 VI 1643]; R 2347, k. 171ver. [5 XII 1648] itd.

122 BUWr, sygn. R 2348, k. 114rec. [16 VIII 1649]; R 2348, k. 114ver. [17 VIII 1649]; R 2348, k. 161ver. [21 XI 1649].

${ }^{123}$ BUWr, sygn. R 2358 k. 54rec. [18 IV 1659]; R 2358, k. 74ver. [29 V 1659]; R 2358, k. 78ver. [6 VI 1659]; R 2358, k. 93ver. [6 VII 1659].

${ }^{124}$ BUWr, sygn. R 2344, k. 3rec. [2 I 1645]; R 2344, k. 31rec. [1 III 1645]. 
Maior dyskutował czasem z Profem na temat muzyki, np. przy okazji wydania przez tego ostatniego w Lipsku zbioru koncertów kościelnych ${ }^{125}$. Wrocławski rektor rozmawiał de re Musica z Cargiusem $^{126}$, z którym również spotykał się na wspólnych posiłkach uświetnianych muzyką ${ }^{127}$. Muzyka mogła być też przedmiotem rozmów podczas kolacji z Akolutem ${ }^{128}$, choć Maior pisał o niej tylko wtedy, gdy bywał gościem u innego wrocławskiego autora pieśni, Mattheusa Apellesa von Löwensterna ${ }^{129}$. Podczas ostatniego spotkania Maiora z Apellesem w jego domu stawili się „Musici, qui $\&$ voce $\&$ instrumentis musicis hanc carnivalem conversarem $\&$ piam $\&$ suavum reddidere" ${ }^{130}$. Wśród zaproszonych znalazł się także młody nauczyciel Elisabetanum Daniel Sartorius, określany przez Maiora jako „juvenus doctissimus i philologus eximus"131. Odziedziczył on po Profiusie pokaźną kolekcję włoskich druków muzycznych wykorzystywanych w praktyce dydaktycznej elżbietańskiego gimnazjum ${ }^{132}$. Uczestnikami domowych biesiad z muzyką byli też znani Maiorowi organiści, m.in. zatrudnieni we wrocławskim kościele św. Marii Magdaleny: Bernhard Beyer ${ }^{133}$ i Tobias Zeutschner ${ }^{134}$, a także Sigismund Franck ze Środy Śląskiej ${ }^{135}$, Andreas Rauch z Legnicy ${ }^{136}$ oraz Johannes Kessel z Oleśnicy ${ }^{137}$.

Wzmianki na temat muzyki pojawiają się także w relacjach Maiora $\mathrm{z}$ recreationes in tabula oblonga odbywanych w kręgu przyjaciół w ich

125 BUWr, sygn. R 2340, k. 25rec. [15 II 1641]: „Dn. Ambrosius Profius mecum coenabat, collocutus quoddam mecum de Epta Dedicatoria Cantilenis quaebundam Harmonicis Lipisae edendis, promittendam". Prawdopodobnie chodziło o Erster Theil Geistlicher Concerten und Harmonien à 1. 2. 3. 4. 5. 6. 7. Ec Vocibus [...] zum öffentlichen Druck befördert durch Ambrosium Profium, Organisten zu St. Elisabeth in Bresslaw, Leipzig 1641.

${ }^{126}$ BUWr, sygn. R 2342, k. 53rec. [14 IV 1643].

127 BUWr, sygn. R 2347, k. 118ver. [21 VIII 1648].

${ }^{128}$ BUWr, sygn. R 2363, k. 137ver. [28 IX 1664]; R 2366, k. 126rec. [5 IX 1667]; R 2368, k. 5rec. [6 I 1669].

${ }^{129}$ BUWr, sygn. R 2342, k. 107rec. [1 VIII 1643].

130 BUWr, sygn. R 2347, k. 37rec. [11 III 1648].

${ }^{131}$ BUWr, sygn. R 2344, k. 138rec. [1 X 1645]; R 2346, k. 150ver. [24 X 1647].

132 T. Jeż, The Italian Music Collection of Daniel Sartorius from Breslau, s. 177.

133 BUWr, sygn. R 2344, k. 161 [16 XI 1645]; R 2363, k. 56rec. [18 IV 1664].

${ }_{134}$ BUWr, sygn. R 2348, k. 61ver. [3 V 1649]; R 2354, k. 168ver. [3 XII 1655].

135 BUWr, sygn. R 2340, k. 80ver. [6 VI 1641].

136 BUWr, sygn. R 2344, k. 153ver. [1 XI 1645].

137 BUWr, sygn. R 2354, k. 99 [17 VII 1655]; R 2354, k. $101 \mathrm{rec}$. [21 VII 1655]. 
podmiejskich ogrodach, m.in. u Augusta Vollgnada ${ }^{138}$. Te wesołe convivia, z udziałem takich gości jak: Mattheus Appelles, Ambrosius Profe, Daniel Sartorius, często zdobiła muzyka, wykonywana zarówno przez samych biesiadujących, jak i zaproszonych na tę okazję profesjonalistów ${ }^{139}$. Muzykę usłyszeć też było można podczas wycieczek za Odrę lub Oławę, odbywanych przez Maiora z rodzinami Apellesa i Profego. Kończyły się one często biesiadami w podmiejskich gospodach ${ }^{140}$. W czasie jednej z nich rektor wrocławskiego gimnazjum zanotował nawet graną tam przez miejscowego skrzypka melodię:

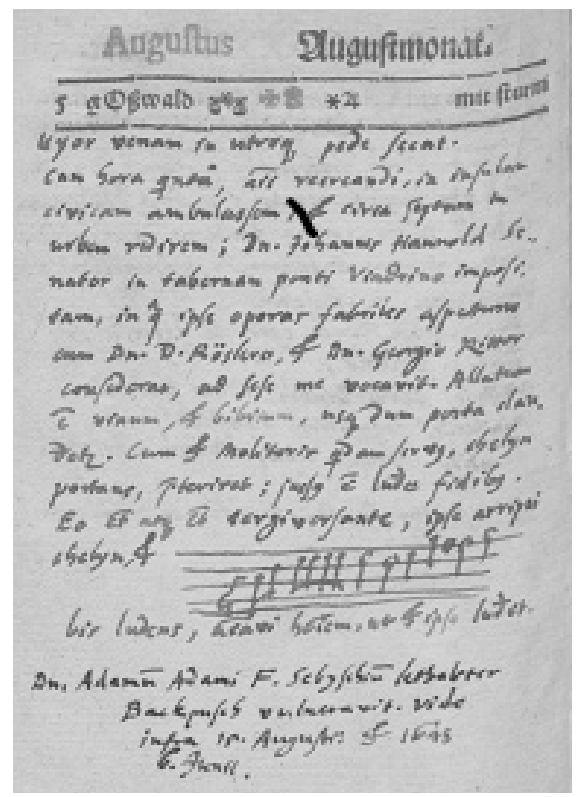

Il. 3. BUWr, Oddział Rękopisów,

R 2346, fol. 110ver. (5 VIII 1647)

Działalność dydaktyczna w gimnazjum, organizacja spektakli teatralnych, aktywny udział w życiu liturgicznym, spotkania i rozmowy z przyjaciółmi, biesiady w podmiejskich ogrodach miasta - wszystkie

${ }^{138}$ BUWr, sygn. R 2339, k. 126ver. [6 IX 1640]; R 2339, k. 130rec. [13 IX 1640]; R 2340, k. 77rec. [30 V 1641] itp.

${ }_{139}$ BUWr, sygn. R 2348, k. 7rec. [10 I 1649]; R 2345, k. 92rec. [20 VI 1646].

140 BUWr, sygn. R 2344, k. 86rec. [19 VI 1645]. 
te formy aktywności składają się na bardzo wyrazisty portret Eliasa Maiora. Z zapisanych przezeń Schreibkalender wyłania się sylwetka wszechstronnie wykształconego humanisty: zaangażowanego w doskonalenie procedur kształcenia, nauczanie łaciny i egzekwowanie szkolnej dyscypliny, głęboką pobożność pasyjną i przeżywaną w kręgu znajomych radość życia. Wszystkie te przejawy aktywności łączy wrażliwość na piękno muzyki, harmonijnie łączącej domeny cultus externus oraz internus, sfery publiczną i prywatną, sztukę oraz naturę, pracę i odpoczynek, a także szukanie rymów do epitalamiów i picie wina, nawet ultra mediocritatem ${ }^{141}$. Humanizm Maiora, potrafiącego równie umiejętnie odnaleźć się na podium własnej uczelni, w chórze swojej parafii, na ławie magistratu i za stołem w podmiejskim ogrodzie, znalazłby chyba uznanie zarówno Erazma, jak i Melanchtona. Ucieszyłby też Wawrzyńca Korwina, który - udając się po obiedzie nad Odrę - spotkał tam patronujących Elisabetanum - Apollina ze wszystkimi dziewięcioma Muzami:

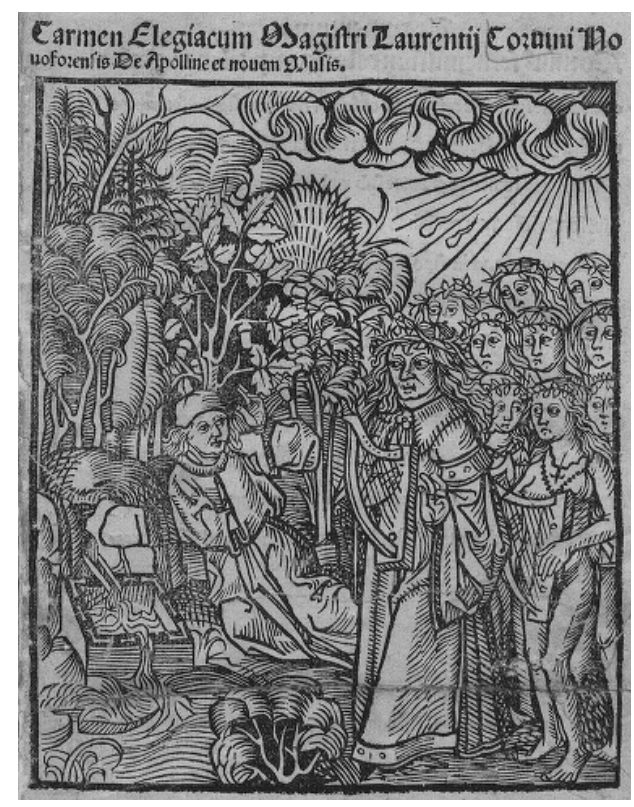

Il. 4. Carmen elegiacum Magistri Laurentij Coruini [...] De Apolline et nouem Musis, Breslau 1503, BJ, sygn. St. Dr. Cim. 5151

${ }^{141}$ BUWr, sygn. R 2345, k. 6ver. [9 I 1646]. 


\section{Bibliografia}

Ch. Absmeier, Szkoty a region: szkolnictwo ślaskie wieku reformacji, tł. M. Kulisz, „Śląska Republika Uczonych”, 3, 2008, s. 121-132

R. J. Alexander, Zum Jesuitentheater in Schlesien. Eine Übersicht, w: Funde und Befunde zur schlesischen Theatergeschichte, I., Dortmund 1983

J. C. Arletius, Historischer Entwurf von den Verdiensten der Evangelischen Gymnasiorum in Breslau um die deutsche Schaubühne, Breslau 1762

G. Bauch, Beiträge zur Literaturgeschichte des schlesischen Humanismus, „Zeitschrift des Vereins für Geschichte und Altherthum Schlesiens", 30, 1896, s. $127-164$

G. Bauch, Geschichte des Breslauer Schulwesens in der Zeit der Reformation, Breslau 1911 (Codex Diplomaticus Silesiae, t. 26)

G. Bauch, Laurentius Corvinus, der Breslauer Stadtschreiber und Humanist, „Zeitschrift des Vereins für Geschichte und Althertum Schlesiens”, 17, 1883, s. 230-302

Das Breslauer Schultheater im 17. und 18. Jahrhundert. Einladungsschriften $z u$ den Schulactus und Szenare zu den Aufführungen förmlicher Comödien an den protestantischen Gymnasien, hrsg. von K. Gajek, Tübingen 1994

J. Budzyński, Dramat i teatr szkolny na Ślasku (XVI-XVIII wiek), Katowice 1996

J. Budzyński, Paideia humanistyczna czyli wychowanie do kultury. Studium z dziejów klasycznej edukacji w gimnazjach XVI-XVIII wieku (na przyktadzie Ślaska), Częstochowa 2003

M. Burbianka, Andrzej Winkler - drukarz wroctawski XVI wieku, „Roczniki Biblioteczne", 4, 1960, s. 329-445, 636-638

J. H. Cunradus, Silesia Togata, ed. by C. T. Schindlerus, Lignicii 1706

M. P. Fleischer, Die Konkordienformel in Schlesien, „Jahrbuch für schlesische Kirchengeschichte", 58, 1979, s. 50-83

J. L. Flood, Poets Laureate in the Holy Roman Empire. A Bio-bibliographical Handbook, vol. 1-4, Berlin 2006

K. Garber, Das Alte Breslau. Kulturgeschichte einer geistigen Metropole, Köln-Weimar-Wien 2014

M. Hancke, Vratislaviensis Eruditiones Propagatores: Id est, Vratislaviensium Scholarum Presides, Inspectores, Rectores, Professores, Praeceptores Tabulis Chronologicis comprehensi, Leipzig 1701

J. Harasimowicz, Ślaski luteranizm wieku Reformacji - próba charakterystyki, „Śląski Kwartalnik Historyczny Sobótka”, 39, 1984, nr 4, s. 493-516

M. Hippe, Aus dem Tagebuche eines Breslauer Schulmannes im siebzehhnten Jahrhundert, w: Breslauer Studien. Festschrift des Vereins fur Geschichte und Althertum Schlesiens zum fünfundzwanzigjährigen Amtsjubiläum seines Vizepräses Hermann Markgraf, Breslau 1901, s. 159-192

T. Jeż, The Italian Music Collection of Daniel Sartorius from Breslau, w: Music Migration in the Early Modern Age. Centres and Peripheries - People, Works, 
Styles, Paths of Dissemination and Influence, eds. by J. Guzy-Pasiak, A. Markuszewska, Warszawa 2016, s. 171-182

T. Jeż, Kultura muzyczna jezuitów na Ślasku i ziemi kłodzkiej (1581-1776), Warszawa 2013

T. Jeż, Stypendia wroctawskiej Rady Miejskiej jako instytucja ksztatcenia kadr muzycznych w latach 1550-1650, „Ślaska Republika Uczonych”, 3, 2008, s. $155-181$

T. Jeż, $Z$ przesztości muzycznej wroctawskiego kościota św. Elżbiety w czasach baroku, „Muzyka. Kwartalnik Instytutu Sztuki Polskiej Akademii Nauk”, 52, 2007, nr 4, s. 83-111

P. Konrad, Die Einführung der Reformation in Breslau, Breslau 1917

G. McDonald, Laurentius Corvinus a renesansowe miasto Wroctaw, w: Wroctaw literacki, red. M. Kopij, W. Kunicki, T. Schulz, Wrocław 2007, s. $47-62$

L. Noack, Christian Hoffmann von Hoffmannswaldau (1616-1679). Leben und Werk, Tübingen 1999

Philippi Melanchthonis opera quae supersunt omnia, hrsg. von C. G. Bretschneider, Halle 1834 (Corpus Reformatorum, t. 1)

A. Rombowski, Wydawcy Wielkiego Kancjonatu Wroctawskiego z roku 1673, „Pamiętnik Literacki”, 45, 1954, nr 3, s. 212-234

H.-A. Sander, Beiträge zur Geschichte des Lutherischen Gottesdienstes und der Kirchenmusik in Breslau. Die lateinische Haupt- und Nebengottesdienste im 16. und 17. Jahrhundert, Breslau 1937

J. Sass, Die kirchenmusikalischen Ämter und Einrichtungen an den drei evangelischen Haupt- und Pfarrkirchen der Stadt Breslau, Breslau 1922

J. Soffner, Geschichte der Reformation in Schlesien, Breslau 1886

R. Starke, Ambrosius Profe, „Monatshefte für Musikgeschichte”, 34, 1902, nr 11, s. 189-196; nr 12, s. 199-215

R. Starke, Kantoren und Organisten der St. Elisabethkirche zu Breslau, „Monatshefte für Musikgeschichte", 35, 1903, nr 3, s. 41-48

\section{From the Diaries of a Musical Scholar. Schreibkalender by Elias Maior (1588-1669) as a Source for the History of Wrocław Musical Culture}

Already at the end of the fifteenth century the Saint Elisabeth middle school (St. Elisabeth-Gymnasium) at Wrocław was a key centre of Silesian humanities, owing its reputation to, among others, Laurentius Corvinus (in Polish Wawrzyniec Korwin) and other graduates of the Cracov University. A next generation of St. Elisabeth-Gymnasium's teachers studied in Wittenberg, also at Philip Melanchthon's, who exerted a profound impact on Wroctaw's 
intellectual elites. The Reformation introduced to the churches of the city was accompanied by a reform of education that made it possible in 1562, under Vice-Chancellor Andreas Winkler, to grant the school the status of gymnasium. Also the following vice-chancellors of Elisabetanum were guided by humanist ideals, including Elias Maior (1631-1669), who greatly developed a tradition of performing theatre plays.

Elias Maior's literary and didactic achievements are set in an interesting interpretative context in his Schreibkalender - diaries he kept for several decades of his vice-chancellorship. These notes are an extremely rich source documenting the everyday life of St. Elisabeth-Gymnasium's vice-chancellor, both in publicis: in his school, his parish church and in the municipal council; and privatim: at his friends' places, gardens, and taverns. What merits special attention here are numerous references to music played in all those circumstances. All this reveals a unique picture of musical life of the city on the Oder painted by the Wrocław's learned Poeta Lauretaus.

Tomasz Jeż studiował muzykologię w Warszawie, Getyndze i Berlinie. Po promocji doktorskiej (2002) zatrudniony w Instytucie Muzykologii UW na stanowisku adiunkta. W ramach programu „Kolumb” Fundacji na rzecz Nauki Polskiej odbył staż naukowy w Rzymie (2007/2008). Jest autorem trzech książek i 60 artykułów, poświęconych zagadnieniom źródłoznawczym i ideowym aspektom kultury muzycznej. Jego głównym polem badań jest kultura muzyczna Śląska i Rzeczypospolitej Obojga Narodów w XVI-XVIII w.

Tomasz Jeż studied musicology in Warsaw, Göttingen and Berlin. Having received his $\mathrm{PhD}$ (2002), he was employed as assistant professor at the Institute of Musicology, University of Warsaw. For the 2007/2008 academic year he received the postdoc scholarship of the Foundation for Polish Science at Rome. He is the author of three books and over sixty studies and articles on heuristic and spiritual contexts of the music culture. His scholarly interest focuses on the music culture of Silesia and the Polish-Lithuanian Commonwealth in the $16^{\text {th }}-18^{\text {th }}$ centuries.

E-mail: tomasz.jez@uw.edu.pl 